EGU Stephan Mueller Special Publication Series, 2, 193-206, 2002

(C) European Geosciences Union 2002

\title{
Geophysical evidences of continental break up in the southeast of the Democratic Republic of Congo and Zambia (Central Africa)
}

\author{
M. N. Sebagenzi ${ }^{1,2}$ and K. Kaputo ${ }^{1}$ \\ ${ }^{1}$ Geological Department, GECAMINES-Likasi (D.R. Congo), 30-32 Boulevard du Souverain, 1170 Brussels, Belgium \\ ${ }^{2}$ Geological Department, University of Lubumbashi, BP 1825 Lubumbashi, D.R. Congo
}

Received: 30 November 2000 - Revised: 2 September 2002 - Accepted: 31 October 2002

\begin{abstract}
This paper reviews the available gravity, heat flow and seismolocal data to better understand recent rifting mechanisms in the southeast of the Democratic Republic of Congo and Zambia. In previous studies the compilation of gravity data led to define a low regional Bouguer anomaly of -140 mgal amplitude with NE-SW axis parallel to the trend of the young rifts Upemba and Mwero in the Democratic Republic of Congo, Luano, Luangwa and Lukusashi in Zambia. Analysis of relationships between Bouguer anomaly and elevation reveals for the whole region an isostatic disequilibrium related to a 2-D model of low-density asthenosphere $\left(-0.06 \mathrm{~g} / \mathrm{cm}^{3}\right)$ implying thin lithosphere thick of $123 \mathrm{~km}$ with associated rifting. Heat flow results, structural and seismological data contribute to support the rifting model in which an active thermal disturbance is occurring in the form of an actively upwelling stream of asthenospheric material which began during the Early Cenozoic when Arabia rifted from Africa and the East Africa Rift system developed. A new view of the rifting geodynamics is presented showing that the main continental break up of Africa south of $10^{\circ} \mathrm{S}$ may occur in future through the southeast of the Democratic Republic of Congo and Zambia rifting evolution dependent on the extent of the upwelling of the asthenosphere.
\end{abstract}

\section{Introduction}

The early break up of African part of Gondwana has already been discussed by several authors as model which deal with the relationship between the development of KarooMesozoic rifts and the opening of South Atlantic (e.g. Fairhead, 1988; Fairhead and Binks, 1991; Guiraud and Maurin, 1992). This episode of rifting has been followed by a second one during the Cenozoic when the Arabian Plate moved

Correspondence to: M. N. Sebagenzi

(ssebagenzi@yahoo.fr.) away from Africa and the East African Rift System (EARS) developed in response to an upwelling of the asthenosphere (e.g. Fairhead, 1976; Achauer, 1992; Sebagenzi, 1997).

Two branches of the EARS are classically distinguished. From the Red Sea southward the Eastern Branch cuts through the Kenya and Tanzania Domes and its southeastward propagation across the Mozambique Channel to the Davie RidgeMadagascar region has been established (e.g. Grimison and Chen, 1988). The Western Branch which developed on the Proterozoic mobile belts surrounding the Tanzanian Archean craton (McConnell, 1972; Delvaux, 1991), extends for more than $2500 \mathrm{~km}$ from the northeast of the Democratic Republic of Congo (D.R. Congo) to the northern part of Lake Malawi. It is occupied by the Mobutu (Albert), Idi Amin (Edward), Kivu, Tanganyika, Rukwa and Malawi (Nyansa) rift valleys. The southeast of the D.R. Congo and Zambia are situated in the south of the Tanganyika rift (Fig. 1). This region is of considerable tectonic interest since geological and geophysical studies have shown the existence of active areas related to the Western Branch with a common NE-SW trend (Fairhead and Girdler, 1972; Fairhead and Henderson, 1977; Sebagenzi et al., 1993; Shudofsky, 1985). Therefore, its deep structure remains of crucial importance for understanding the geodynamics of rifting.

In contrast to relatively complete geophysical studies north of $10^{\circ} \mathrm{S}$, the southeast of the D.R. Congo and Zambia did not benefit from a large number of extensive geophysical investigations. Few studies such as gravity, heat flow and seismology are available. All of them have principally been undertaken to test the rifting hypothesis related to an upwelling of the asthenosphere advanced previously by several authors (e.g. Fairhead and Girdler, 1972; Fairhead and Henderson, 1977). According to recent studies, the presence of an upward of the lithosphere-asthenosphere boundary beneath Southeastern D.R. Congo Kundelungu plateau has been suggested by the results of gravity interpretations (Sebagenzi, 


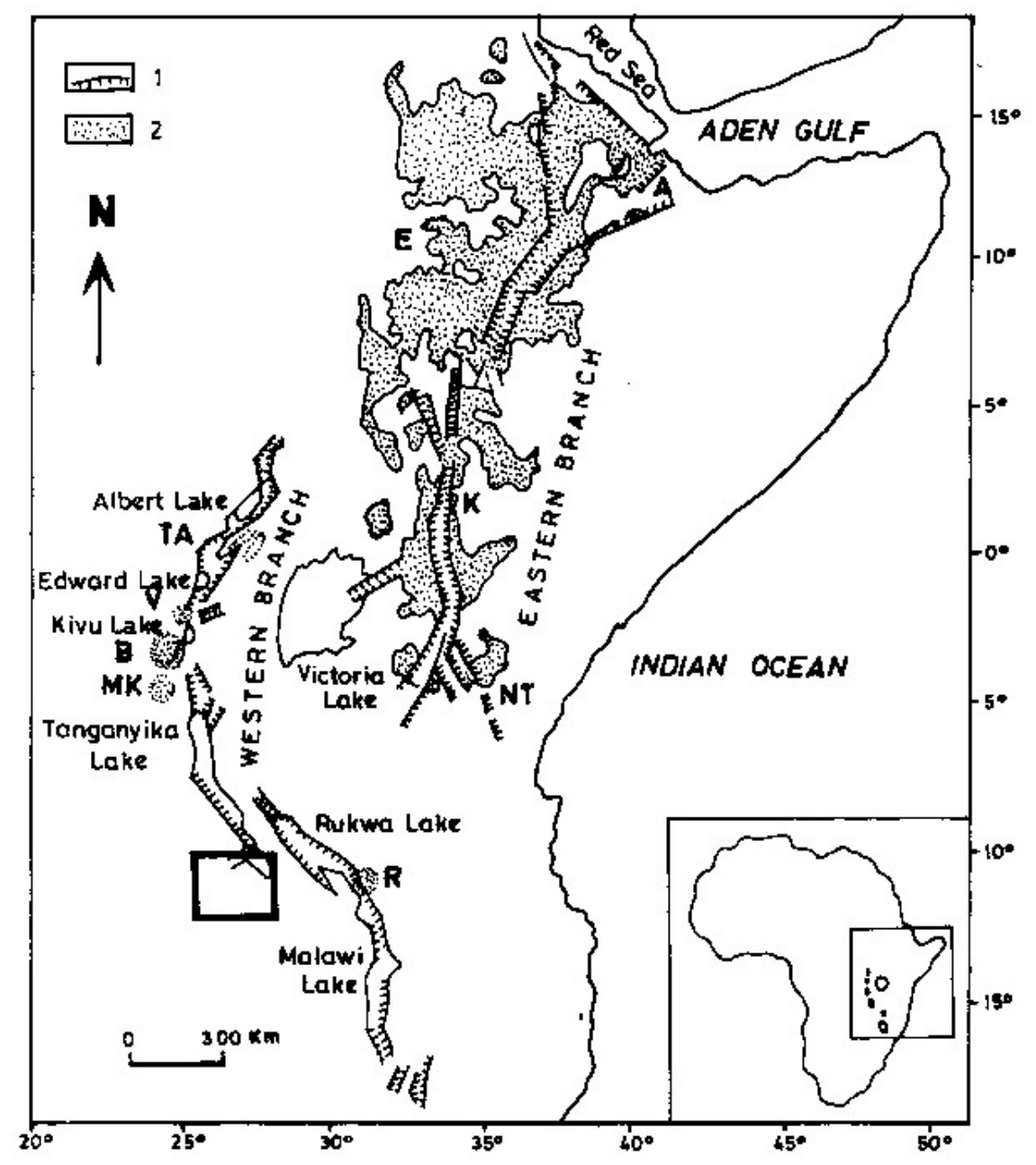

Fig. 1. Structural sketch of the East African Rift System (EARS) showing location of the southeast of the D.R. Congo and Zambia in respect to the EARS (internal carton). Associated Cenozoic volcanic provinces are presented. R: Rungwe; MK: Mwenga Kamituga; B: Bukavu; V: Virunga; TA: Toro-Ankole; NT: Northern Tanzania; K: Kenya; E: Ethiopian Plateau and Rift; A: Afar. 1: Major rift-margin faults; 2: extent of volcanic subprovinves.
1997). The average heat flow value $\left(64 \pm 12 \mathrm{mWm}^{-2}\right)$ higher than expected for this region of Precambrian age has suggested the beginning of partial melting at 85 to $110 \mathrm{~km}$ depth (Sebagenzi et al., 1993). A previousy teleseismic experiment by Fairhead and Reeves (1977) revealed a positive Pwave delay time anomaly of $+0.5 \mathrm{~s}$ which seems to be associated with the gravity low trending NE-SW depicted on the map of Sebagenzi (1997) as well as on the regional Bouguer anomaly for Africa computed from the OSU91A model (Rapp et al., 1991). Seismicity and earthquake-source mechanisms which all are of normal faults show a NWSE tensional stress associated with these reactivated faults which could indicate weakness zones in Precambrian basement (e.g. Dorbath, oral communication; Lombe and Mubu, 1992; Theunissen et al., 1996).

In this paper available geophysical data are reviewed to provide a precious adjunct to assess the state of knowledge about the deep structure in this region. As rifting is a key process in the evolution of the continental crust, the determination of this deep structure would led to better understand rift processes on a global basis.

\section{Summary of structural setting}

Continental rifts follow preferentially preexiting basement weaknesses such as ancient orogenic belts (e.g. Dunbar and Sawyer, 1989; Vauchez et al., 1997). In the southeast of D.R. Congo and Zambia these rifts are associated with belts which developed during the Paleo- and Mesoproterozoic times. The following young rifts are known. The NE-SW trending Upemba, Luano, Lukusashi and Luangwa Karoo and the Mwero Cenozoic rifts (Fig. 2 and 7).

The Upemba, Luano, Lukusashi and Luangwa Karoo basins belong to a major rift system which was linked to a large extensional fault that penetrated deep into Gondwana (Klerkx et al., 1998). These basins contain a relatively complete stratigraphic succession ranging from Late Carboniferous to Early Jurassic, with a marked regional unconformity at the Permian-Triassic transition (Delvaux, 2001). Little is known about the Upemba rift entirely located in D.R. Congo. At the present state of knowledge, only some Upper Carboniferous sedimendary rocks succeeding a basal tillite and Cenozoic terranes are known to have filled the Upemba rift (Mortelmans, 1953; Villeneuve, 1983). Structural studies un- 


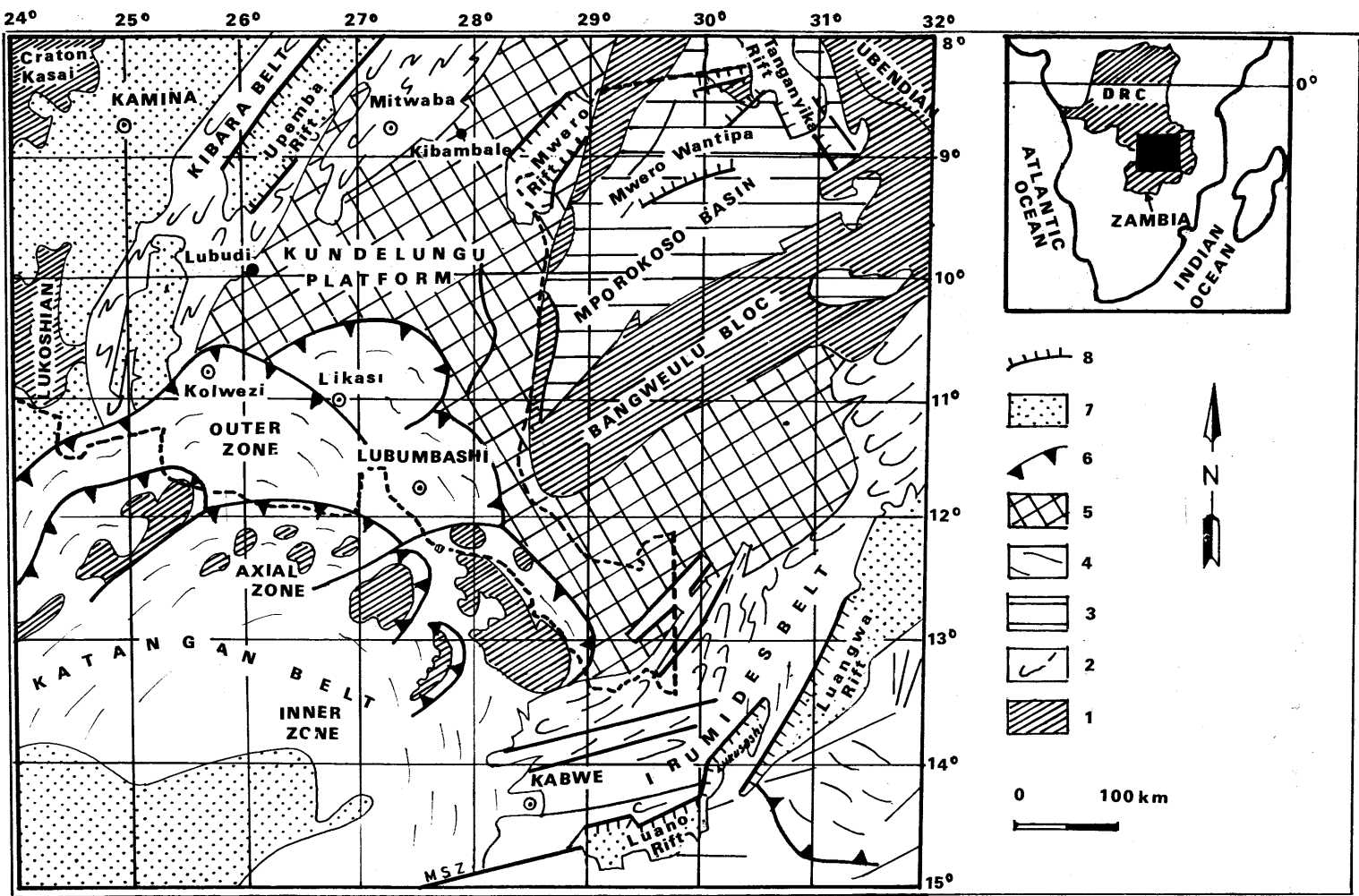

Fig. 2. Geological map of the southeast of DR. Congo and northern Zambia showing the relations between the Katanga belt, the eastern margin of the Kasa craton shield, the Ubendian and Kibara-Irumides belts. Main Mesozoic to present-day rifts are also presented. 1: Archean and Early Proterozoic, 2 and 3: Middle Proterozoic, 4: Neoproterozoic Katangan belt, and 5: its Kundelungu foreland basin, 6: Katangan thrusting, 7: Phanerozoic terranes, 8: active normal faults.

dertaken these years by the team of the University of Lubumbashi would bring news insights in the recent rifting processes in this region.

The south Tanganyika and the Mwero rifts opened during the Cenozoic time. These basins are developed in a large Paleoproterozoic unit named the Bangweulu block in which the most ancient formations consist of a subhorizontal sedimentary cover surrounded by orogenic belt zones which have only affected its periphery (Daly and Unrug, 1983; Unrug, 1984). The rifts generally occur in zones of normally faults with a N115 ${ }^{\circ}$ to $\mathrm{N} 135^{\circ}$ extension (Shudofsky, 1985) associated with either dextral or sinistral strike-slip motions (Mondeguer et al., 1989). Southeastern D.R. Congo and Zambia are composed of active fault structures related to features poorly exposed on the surface; however they are marked by a large negative gravity anomaly and by a seismic activity in a NE-SW trend (Mondeguer et al., 1989).

According to seismological studies, both Karoo and Cenozoic basins are nowadays still opening (e.g. Fairhead and Girdler, 1972; Fairhead and Henderson, 1977; Grimison and Chen, 1988; Lombe and Mubu, 1992). Therefore, further studies are needed to better understanding the geodynamics of rifting in this region. Gravity data collected in 1989 and 1990 and existing geophysical results provide additional information about the possible SE-extension of the EARS into D.R. Congo and Zambia.

\section{Gravity data}

Regional gravity coverage in the Katanga province of the southeast of D.R. Congo has been completed in 1990. About 1900 measurements which have been carried out by the University of Lubumbashi have been conducted with a Lacoste and Romberg $n^{\circ}$ G225 gravimeter while elevations were determined by a Wallace and Tiernan micro-barometer with an average error on altitudes of about $5 \mathrm{~m}$. These data (uncertainty of $\pm 2 \mathrm{mgal}$ ) are not terrain corrected since the area is mostly flat with the exception to the N. and NE. (see Fig. 7). Both points with those from Zambia kindly furnished by the Bureau Gravimétrique International (BGI) of Toulouse (France) which are plotted on Fig. 3 have been used to elaborate the first Bouguer map for the whole region from $10 \times 10 \mathrm{~km}$ grid (Sebagenzi, 1993). The gravity values were referred to the gravity formula based on the 1967 Geodetic Reference System and adopting $2.67 \mathrm{~g} / \mathrm{cm}^{3}$ as the density reduction value. The Bouguer gravity fieId is shown in Fig. 4 in colour coded contour form. The yellow and red coulors represent gravitational highs. The gravity map shows anomalies values ranging between -200 and $-75 \mathrm{mgal}$, with a large negative mean value near $-140 \mathrm{mgal}$. The overall grain of the map is dominantly NE-SW, i.e. the tectonic trend which is well displayed by the known young rifts Upemba and Mwero in the southeast of D.R. Congo and the Luangwa, Lukusashi and Luano in Zambia. 


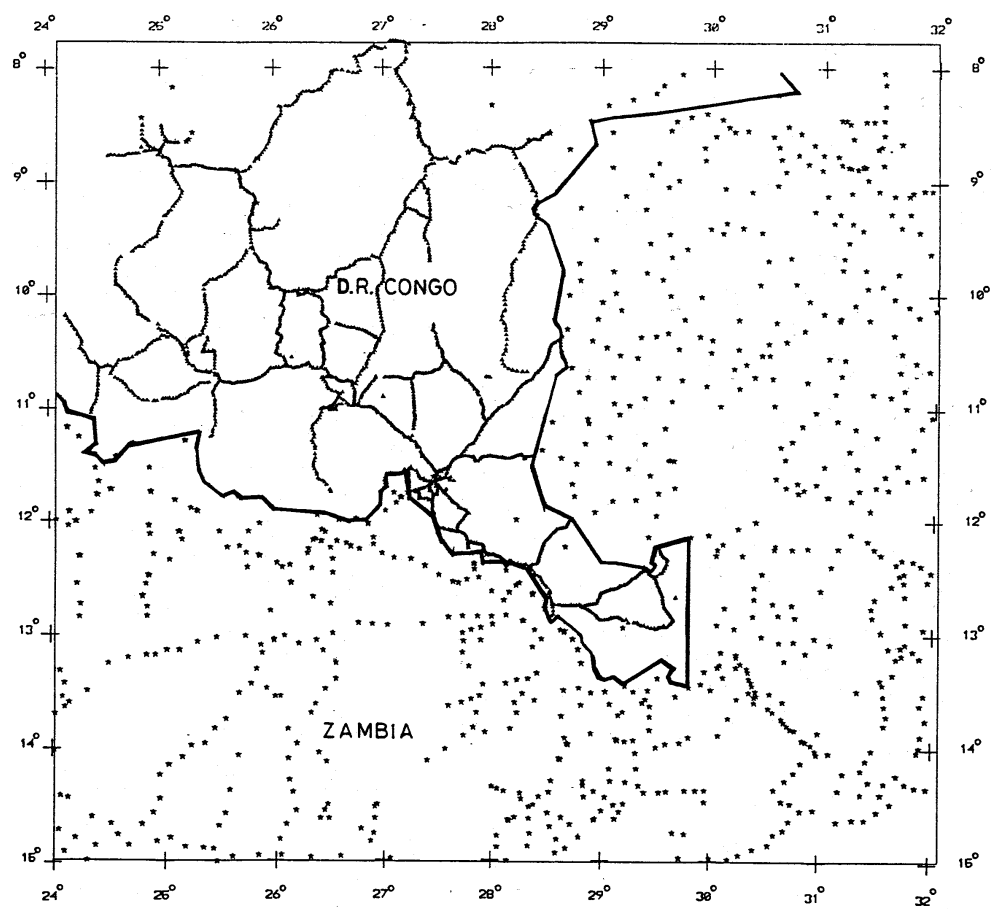

Fig. 3. Distribution of gravity stations used to construct the Bouguer map: stars symbol correspong to gravity measurements from Zambia (Mazac, 1974; Cowan and Pollack, 1977) and to some previous data from the southeast of D.R. Congo (Jones et al., 1960); triangles symbol are stations measured by Sebagenzi (1993).

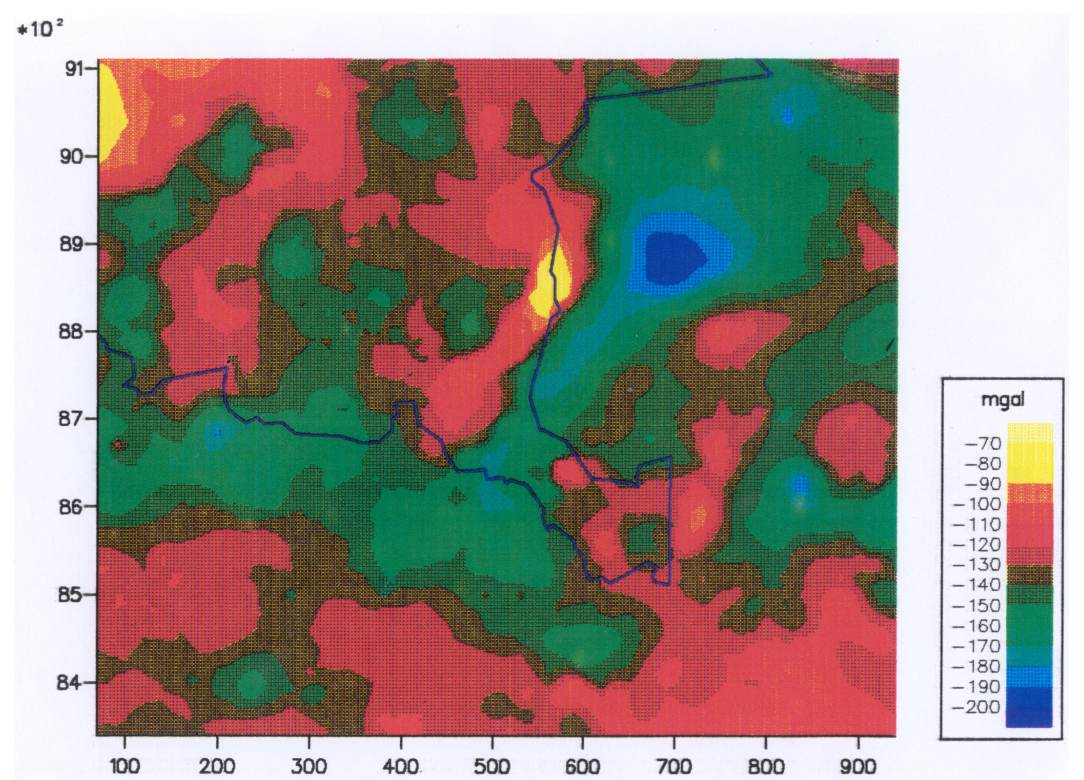

Fig. 4. Bouguer anomaly map of the whole Southeastern D.R. Congo and Northern Zambia computed with a $2.67 \mathrm{~g} / \mathrm{cm}^{3}$ reduction density value. Solid line is of political frontiers.

In order to derive possible model for the lithospheric deep structure, a regional anomaly has been defined in terms of long wavelength Bouguer anomaly. The definition of this long wavelength regional anomaly has been made, assuming for a given profile that the regional anomaly follows closely the observed Bouguer anomaly over the Kibaran (ca.
1400 My.) and Katangan (ca. 820-600 My.) Proterozoic formations. This assumption is thought reasonable since the average density value of Kibaran and Katangan rocks is $2.66 \pm 0.02 \mathrm{~g} / \mathrm{cm}^{3}$ density value close to the $2.67 \mathrm{~g} / \mathrm{cm}^{3}$ value used in the gravity reduction (density measurements were made by E.M.I. Etudes Minières of GECAMINES mining 


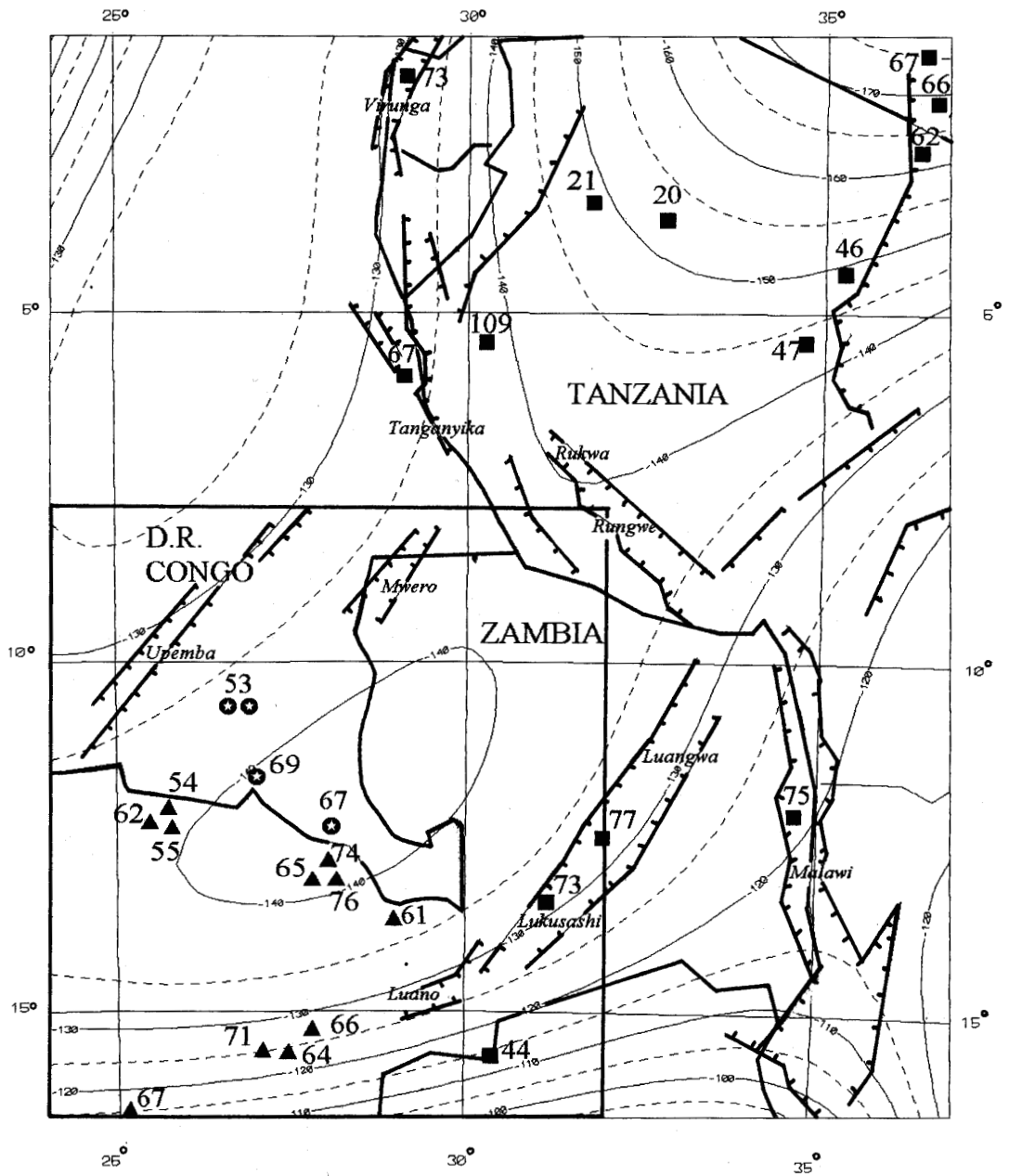

Fig. 5. Regional gravity anomaly map and Heat Flow Determination values at the sites reported from Zambia (solid triangles) by Chapman and Pollack (1977), Kenya and Tanzania (solid squares) by Nyblade et al. (1990) and from D.R. Congo (encircled stars symbol) by Sebagenzi et al. (1993). The SW carton presents the studied region. Barbed lines are of active normal faults; thick lines are of country borders; labeled thin lines and unlabeled dashed lines are of gravity anomalies: curve interval 5 mgal.

company, oral communication and by Sebagenzi, 1993). To define a long wavelength regional anomaly over Southeastern D.R. Congo and Zambia, we have combined our data with those from neighbouring countries Western Malawi, Southern Kenya, Southwestern Tanzania, Burundi and Rwanda which were available, because this definition is more difficult to be done over a reduced-scale area than over a largescale area. Figure 5 presents the computed regional Bouguer anomaly map which corresponds with an analytic surface provided by a 6 order polynomial which was selected by examination of trial fits of several different orders. From this map, south of $10^{\circ} \mathrm{S}$ the gravity low trending NW-SE bisects the region between the Upemba and Luangwa young rifts, where no recent volcanism is known (Fig. 1). However, high heat flow values have been reported from this region by Chapman and Pollack (1977), and Sebagenzi et al. (1993), where the significant level of seismicity indicates that extensional deformations are taking place, suggesting that an incipient arm of the EARS Western Branch extends into Southeastern D.R. Congo and Zambia from Lake Tanganyika (e.g. Maasha and Molnar, 1972; Grimison and Chen, 1988; Lombe and Mubu, 1992; Sebagenzi et al., 1993). The regional Bouguer anomaly over the southeast of D.R. Congo and Zambia agrees with the predicted gravity low depicted on the map of U.S. Defence Agency Aerospace Center published by Slettene et al. (1973), and with the regional Bouguer anomaly for Africa computed from the OSU91A model (Rapp et al., 1991) (Fig. 6). It has recently been demonstrated that the long wavelength Bouguer anomaly over this huge region coincides with the southwestern prolongation of the classic long wavelength anomaly of the EARS which is related to a density drop within the upper mantle (Sebagenzi, 1997; Sebagenzi et al., 1993).

In order to discuss in detail the assumption that lateral variation of density in the upper mantle is the important contributor to the regional Bouguer gravity anomaly, the analysis of relation of gravity to elevation which was used to investigate isostatic equilibrium in terms of the Airy model of lo- 


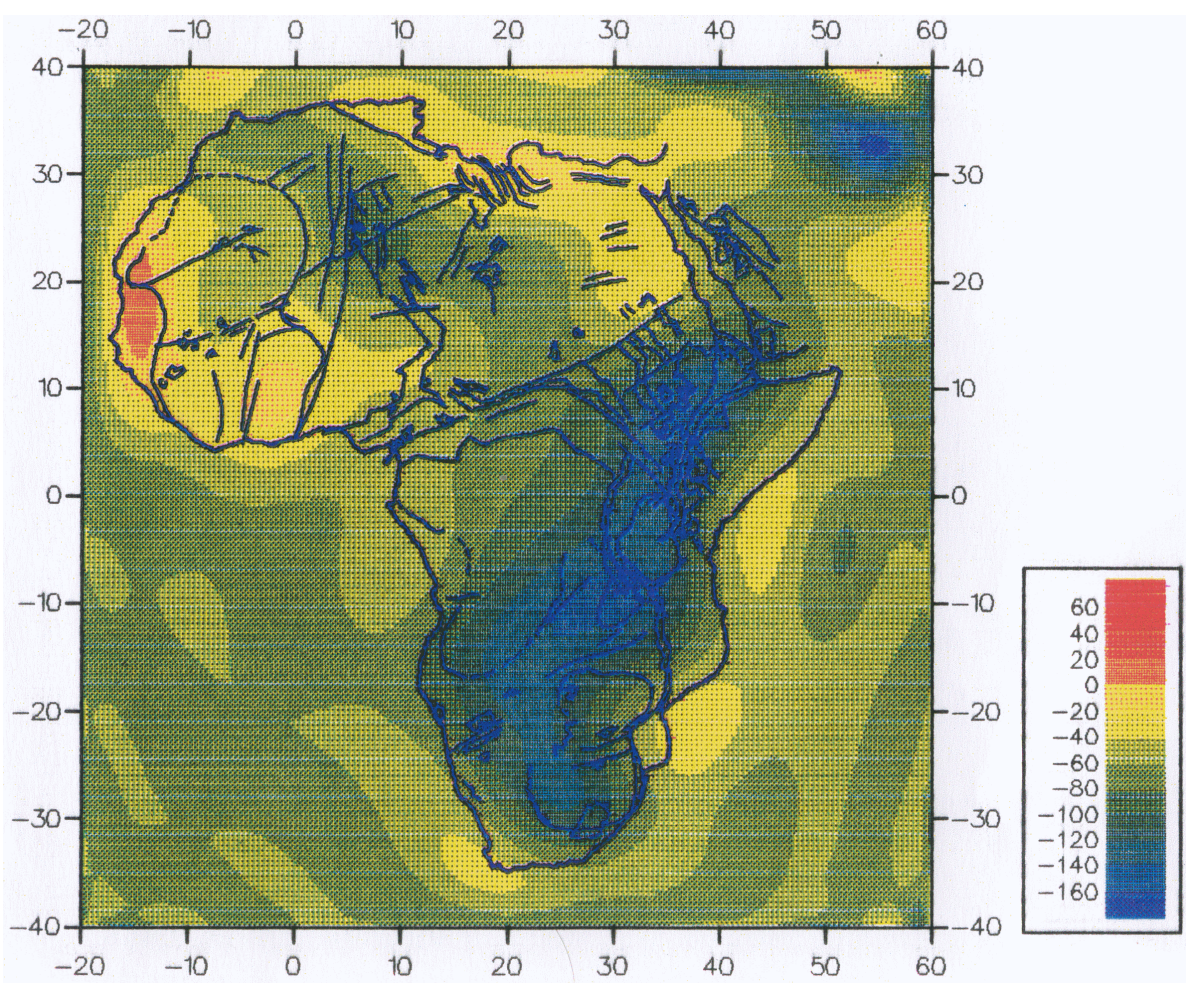

Fig. 6. Regional gravity anomaly for Africa computed from the OSU91A model (Rapp et al., 1991). Main tectonics are presented.

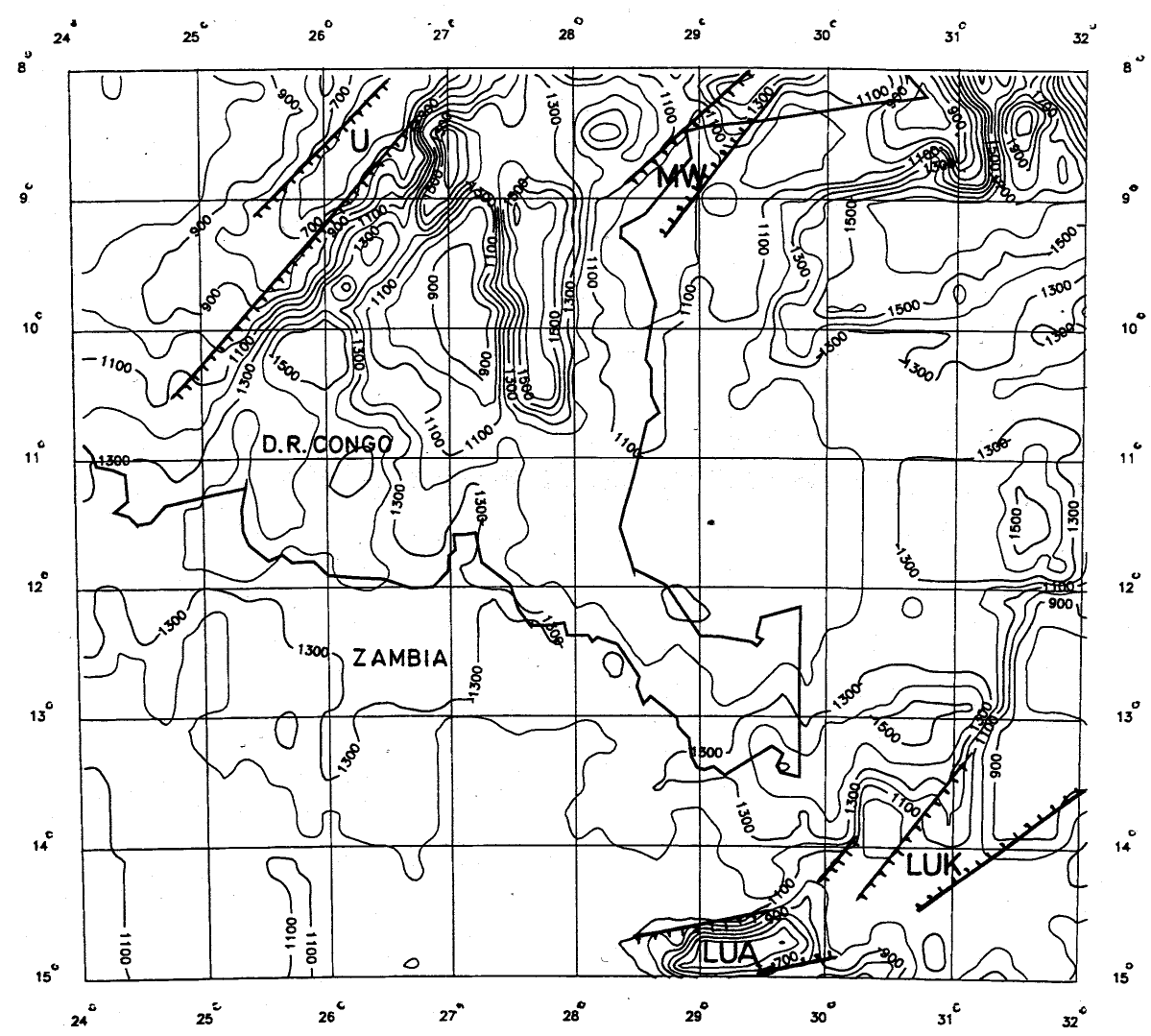

Fig. 7. Simplified topographic map (within $5^{\circ} \times 5^{\circ}$ unit ares) of the southeast of D.R. Congo and northern Zambia. Barbed lines are of active normal faults. Young rifts are shown: MW: Mwero, U: Upemba, LUA: Luano, LUK: Lukusashi. 


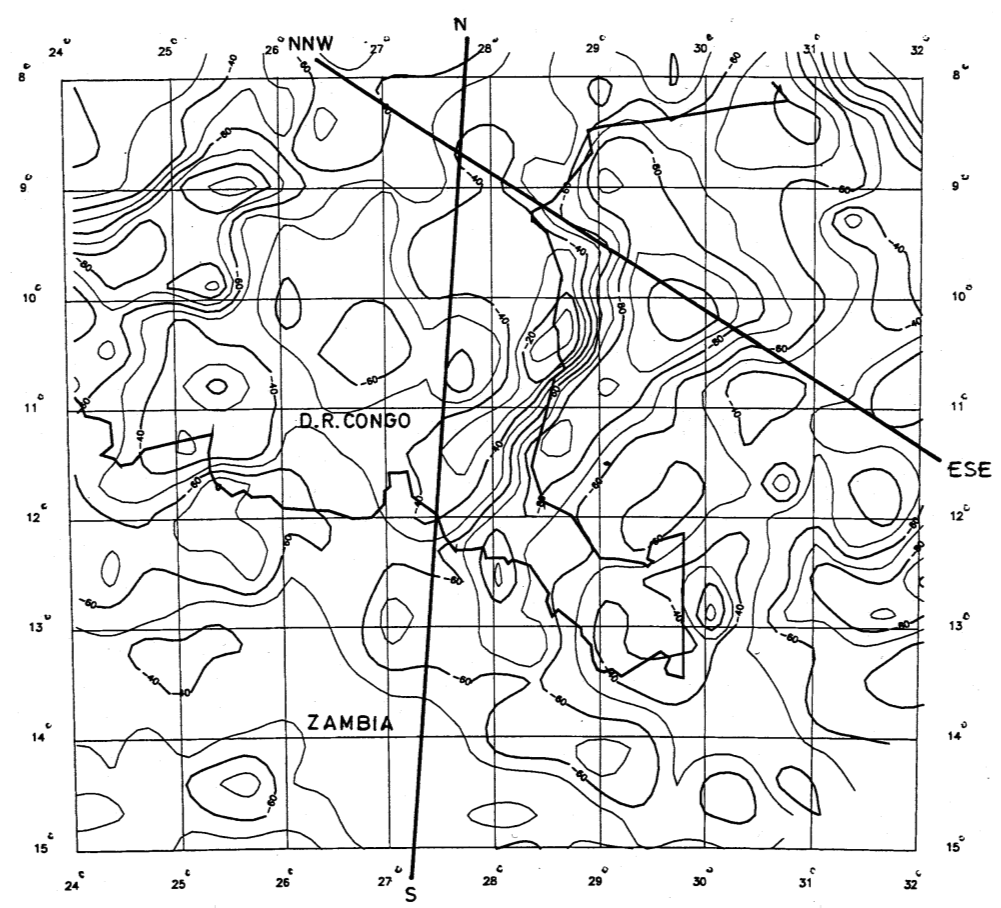

Fig. 8a. Isostatic anomaly map for the whole Southeastern D.R. Congo and Northern Zambia computed for crust model $36 \mathrm{~km}$ thick, $2.7 \mathrm{~g} / \mathrm{cm}^{3}$ average density, $\Delta \rho=-0.45 \mathrm{~g} / \mathrm{cm}^{3}$ density contrast crust-mantle: curve interval $10 \mathrm{mgal}$.

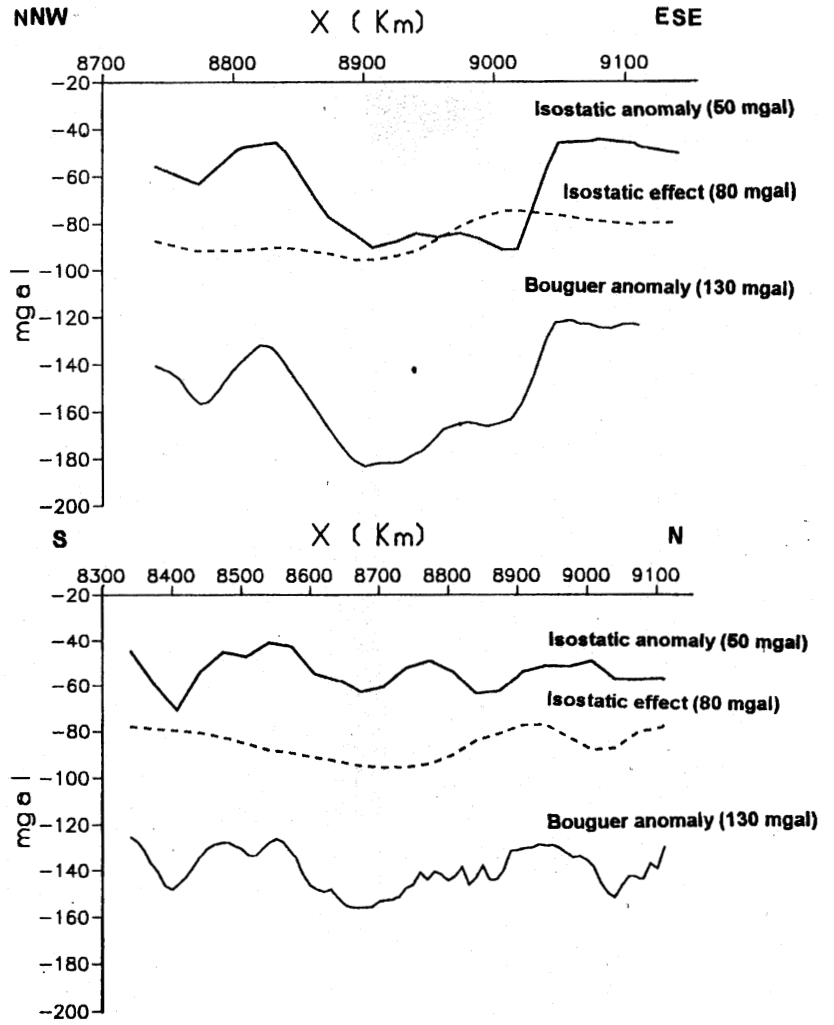

Fig. 8b. Relation between Bouguer anomaly (lower curve), Isostatic anomaly (upper curve) and Isostatic effect (middle curve) for two profiles showing a significant isostatic effet of about $80 \mathrm{mgal}$. See location of these profiles on Fig. 8a. cal isostatic compensation reveals an isostatic unequilibrium over this region of Precambrian age wide of $720000 \mathrm{~km}^{2}$. From elevation point of view, Southeastern D.R. Congo and Zambia are part of the central African Plateau at an average altitude of about $1200 \mathrm{~m}$ above sea-level. In generally the plateau is gently undulating although topographic highs ( $1600 \mathrm{~m}$ and even over $1900 \mathrm{~m}$ in the NE) and topographic lows (500-600 the Luano (LUA) and the Upemba (U) rifts) do exist (Fig. 7). Bouguer anomalies seem to increase from north to south and the Airy model of local isostatic compensation does not fit the observed Bouguer anomaly variation. Using the $2.7 \mathrm{~g} / \mathrm{cm}^{3}$ as the mean density value of crust model $36 \mathrm{~km}$ thick proposed by Hadiouche and Jobert (1988), computations were made with -0.40 and $-0.45 \mathrm{~g} / \mathrm{cm}^{3}$ respectively as density contrast values between crust and mantle. Both density contrast values led to estimate a mean difference of about $80 \mathrm{mgal}$ between Bouguer and isostatic anomaly (Figs. 8a and 8b). This significant isostatic effect higher than the isostatic anomaly amplitude $(50 \mathrm{mgal}) \mathrm{sug}$ gests an isostatic disequilibrium for the whole region which cannot be explained by the properties of the crust because the Lufilian-Katangan which is known to be the last orogeny in this region is of Neoproterozoic age. Therefore, it may result from a low-density upwelling asthenosphere with associated rifting, implying the replacement of the lithosphere by a light asthenosphere (Sebagenzi, 1997).

The modelisation using a 2-D algorithm for the gravitational attraction of polygons (Talwani et al., 1959) led to the gravity model of Fig. 9 (Sebagenzi, 1997). When compared to gravity models in the north of $10^{\circ} \mathrm{S}$, this model is 


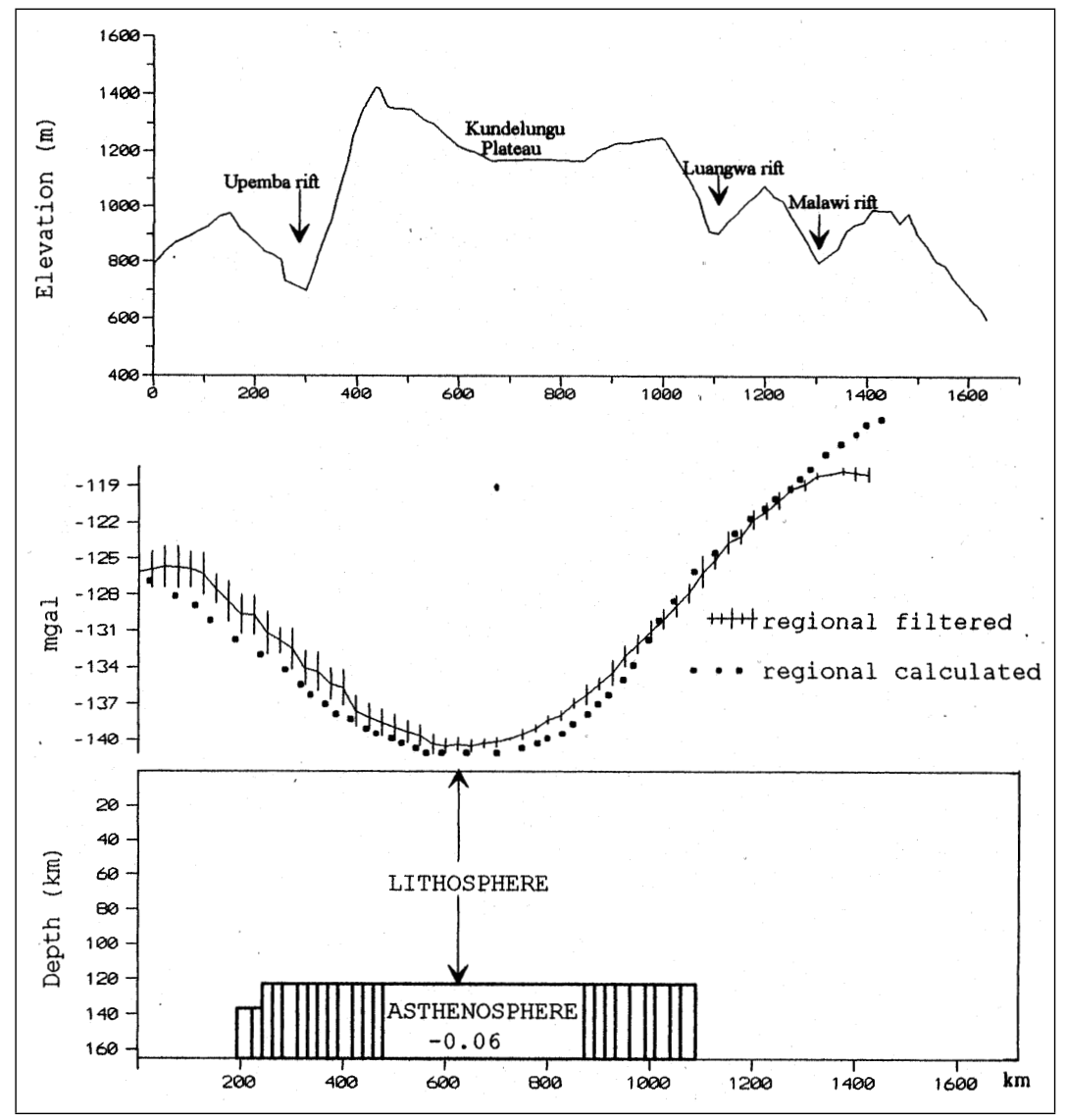

Fig. 9. Gravity model along a profile crossing the Kundelungu plateau, the Upemba, Luangwa and Malawi rifts. Calculations are made using the $-0.06 \mathrm{~g} / \mathrm{cm}^{3}$ as the lithosphereasthenosphere density contrast value (after Sebagenzi, 1997).

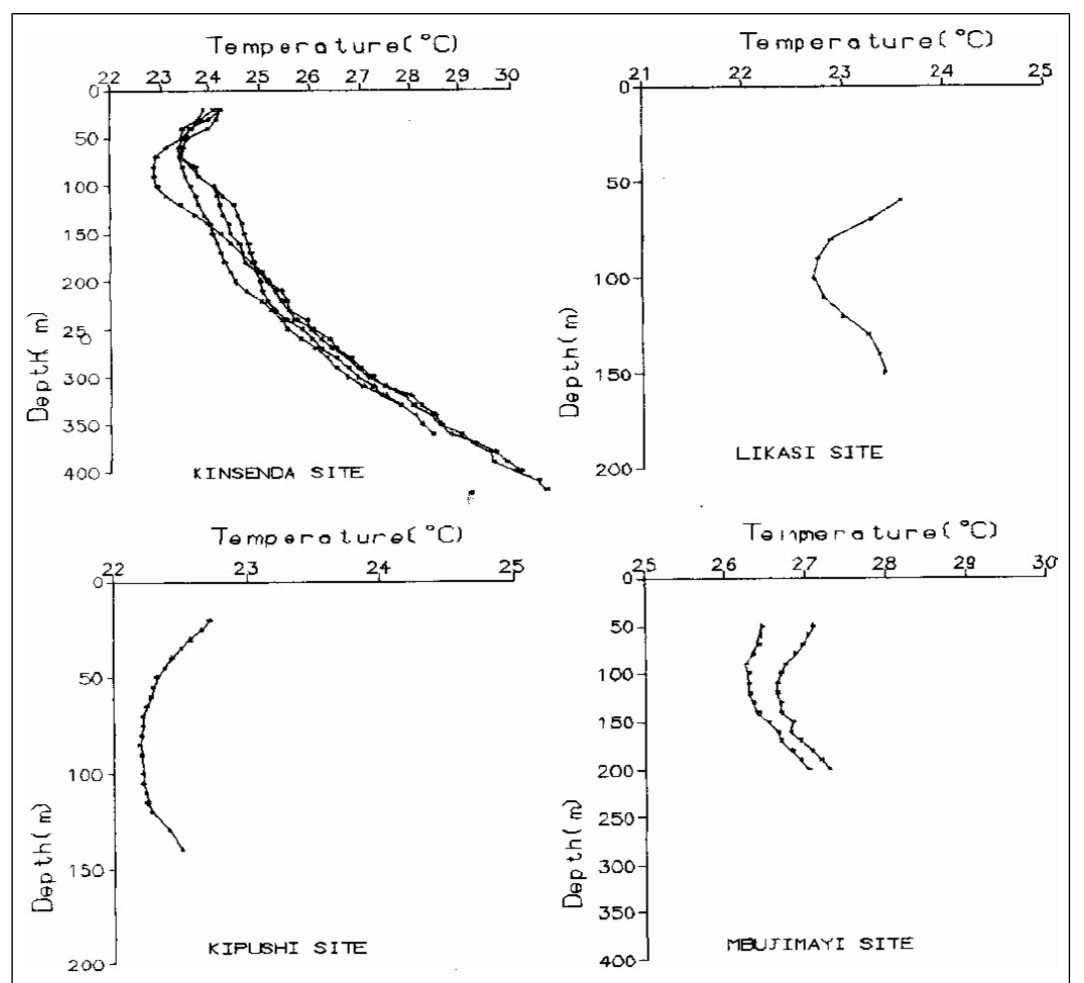

Fig. 10. Temperature profiles for the southeast of D.R. Congo measurements. Boreholes were gathered according to the measurements sites (redrawn from Sebagenzi et al., 1993). 
not confined to a narrow zone in the mantle lithosphere (e.g. Nyblade and Pollack, 1992), but covers a large region of $-0.06 \mathrm{~g} / \mathrm{cm}^{3}$ density contrast value starting at the base of the lithosphere $(165 \mathrm{~km})$ and uprising to $123 \mathrm{~km}$. He is supported by the first Heat Flow Density results perfomed in Southeastern D.R. Congo by Sebagenzi et al. (1993) and in Zambia by Chapman and Pollack (1977).

\section{Heat flow results}

The Heat Flow Density (HFD) have been computed as the product $\mathrm{q}=\mathrm{k}^{*} \mathrm{dT} / \mathrm{dZ}$, where $\mathrm{k}$ is the harmonic mean conductivity on the depth measurement and dT/dZ the undisturbed temperature gradient. Sebagenzi et al. (1993) temperature measurements used in this study have been obtained using mining boreholes with good conductivity control. These boreholes were distributed along the northward convex Neoproterozoic Katangan Arc outside of which no borehole was available. The original intent was to determine the geothermal gradient and measure the associated heat flux from the earth's crust. Data from D.R. Congo were combined with previous HFD results from Zambia to allow initial insight into the thermal regime of the whole region. This data set has a range of 53 to $76 \mathrm{~mW} / \mathrm{m}^{2}$, a mean of $64 \mathrm{~mW} / \mathrm{m}^{2}$ for the various sites and a standard deviation of about $24 \mathrm{~mW} / \mathrm{m}^{2}$ (see Sebagenzi et al., 1993).

The profiles measured in the Katanga province of Southeastern D.R. Congo with a thermistor probe equipment present a negative temperature gradient in the first hundred metres. The relative minimum temperature is found at a depth ranging from 100 to $200 \mathrm{~m}$ and, below this depth the temperature gradient increases until it reaches a constant value (Fig. 10). These observations have been interpreted as a rapid jump of the ground surface temperature in terms of warming, which would propagate downward governing by the thermal diffusivity. Using a least square inversion method, analysis of this anomalous curvature in the uppermost parts revealed that the warming of about $4^{\circ} \mathrm{C}$ amplitude occurred during the last 100 years. It was attributed partially to the deforestation and partially to the climate change (Sebagenzi et al., 1992). This inversion technique yields an estimated undisturbed temperature gradient which was used for HFD determination (Sebagenzi et al., 1993). The obtained $64 \mathrm{~mW} / \mathrm{m}^{2}$ mean HFD value for the various sites which is higher than expected over this region of Precambrian age, lies within the regional heat flow pattern of $68 \pm 4 \mathrm{~mW} / \mathrm{m}^{2}$ average value for the rifted area in the EARS (e.g. Nyblade et al., 1990). Examining close correlation between this higher heat flow mean value and the regional gravity low after the combination of these data with those published by Nyblade et al. (see Fig. 5), Sebagenzi et al. (1993) computed geotherms for the whole region which all showed that high temperatures of $1200-1250^{\circ} \mathrm{C}$ should be attained at $85-110 \mathrm{~km}$ depth, suggesting the possible presence of partial melting zones at shallow depth (Fig. 11). With such results Sebagenzi (1997) therefore pointed out that the long wave-

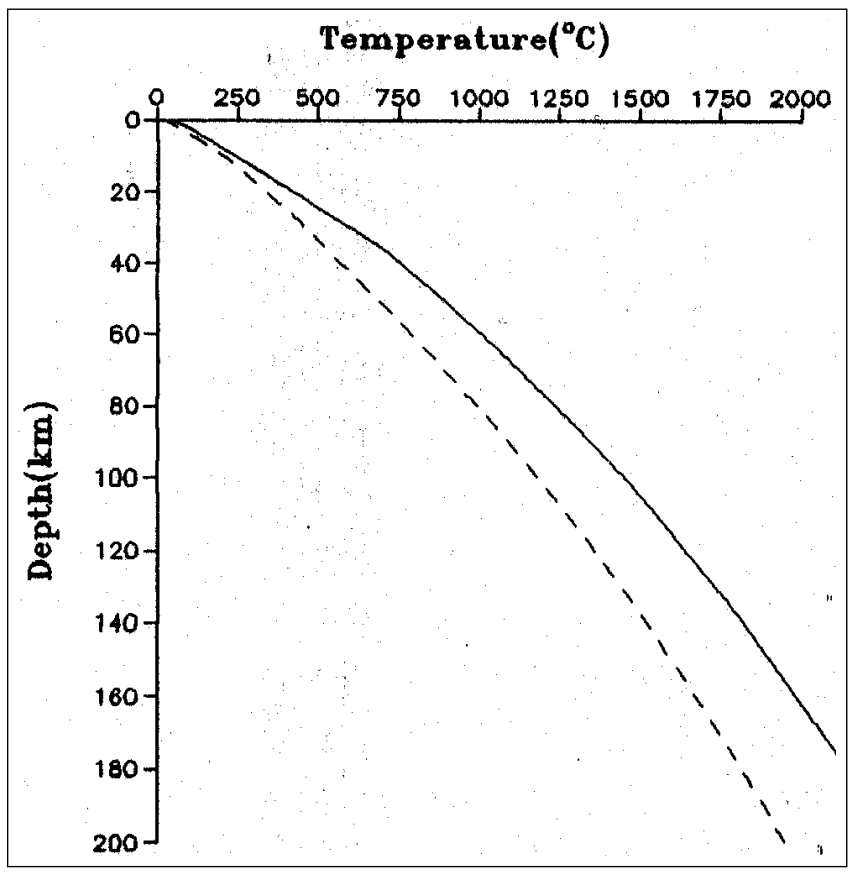

Fig. 11. Geotherms computed with mean surface Heat Flow Determination of $64 \mathrm{~mW} / \mathrm{m}^{2}$. Solid line corresponds to model for apparent $\mathrm{Da}$ of $5.5 \mathrm{~km}$ deduced from HFD and Heat Production relation and dashed line for actual depth of $11 \mathrm{~km}$ (after Sebagenzi et al., 1993).

length negative Bouguer anomaly trending NE-SW, may result from a low-density upper mantle in relation with changes in temperature. Both may be in agreement with low velocities beneath the southeast of D.R. Congo and Zambia.

\section{Seismological data}

Some support for low-velocity, low-density and hot upper mantle zone and model of thinning of the lithosphere along with seismicity and plateau uplift with associated incipient rifting comes from few seismological studies undertaken by several investigators (e.g. Dorbath, oral communication 1992; Fairhead and Henderson, 1977; Fairhead and Reeves, 1977; Hadiouche and Jobert, 1988; Grimison and Chen, 1988; Seno and Saito, 1994).

The study of Fairhead and Reeves (1977) on teleseismic P-wave delay times determination and their correlation with elevation and Bouguer anomaly demonstrated possible presence of low velocities zones beneath the southeast of D.R. Congo and Zambia plateau. Using an inverse relation between lithospheric thickness and delay times, elevation and Bouguer anomaly correlation, this study allowed to infer a thin lithosphere model of about $125 \mathrm{~km}$ thick and revealed that south of $10^{\circ} \mathrm{S}$ the negative Bouguer anomaly is associated with a positive delay time anomaly of about $+0.5 \mathrm{~s}$. To determine this positive delay time anomaly, Fairhead and Reeves used four seismological stations: Delcommune (present Nzilo) in D.R. Congo, Dundo in Angola, 


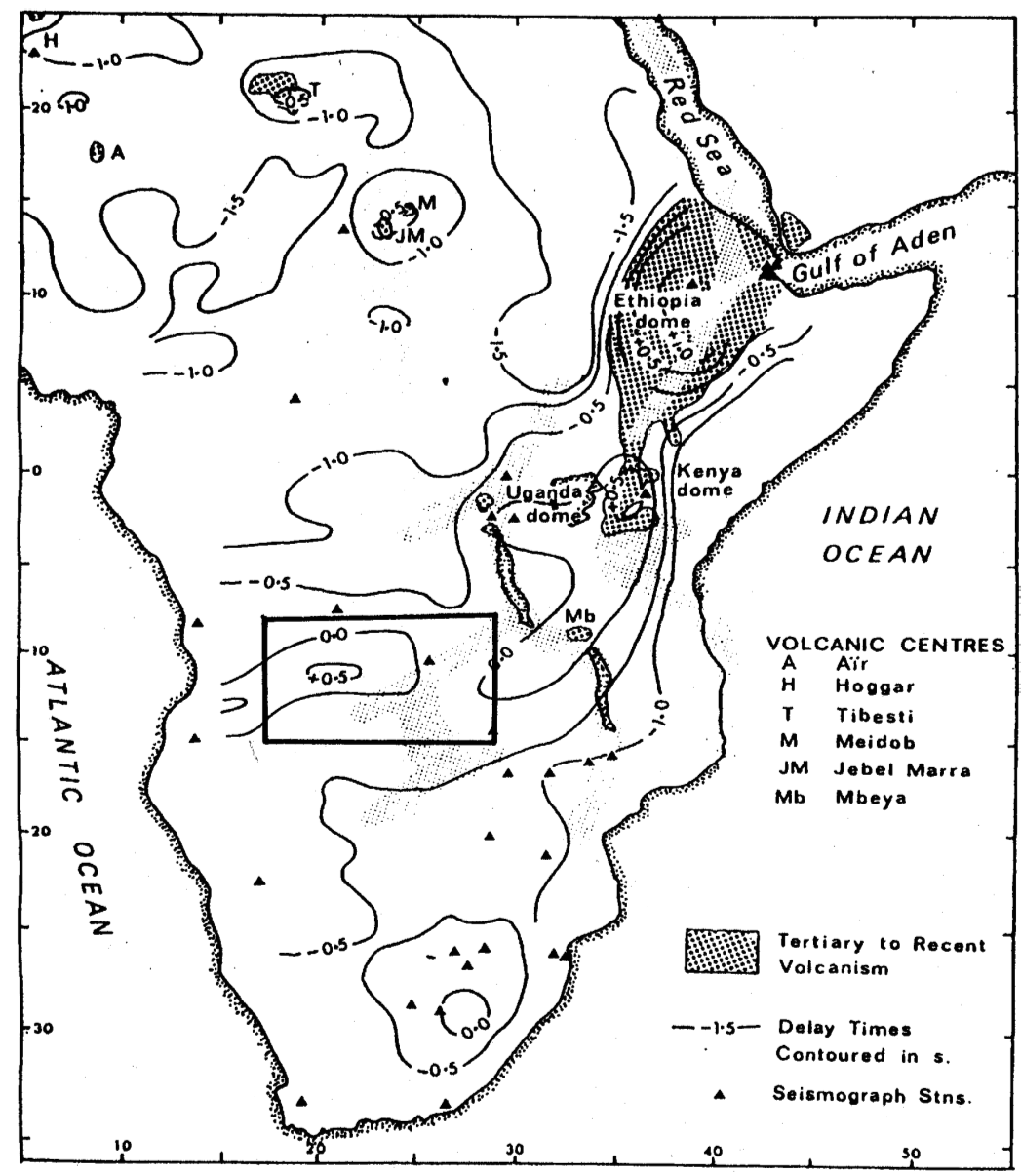

Fig. 12. Teleseismic P-wave delay time map for Africa showing that Southeastern DRC and Zambia are in region of positive delay time anomaly of about $+0.5 \mathrm{~s}$. The internal box shows the location of the investigated area (lightly modified from Fairhead and Reeves, 1977).
Kabwe in Zambia and Karoi in Zimbabwe. For these stations the delay times were computed from the P-wave arrival times which were either read directly from seismograms or from unpublished bulletins. Such study could bring new evidence for a low-velocity zone beneath the studied region, but it could not be undertaken this time unfortunately. It is shown (Fig. 12) that from the Red Sea southward the lowvelocity zone is clearly surrounded by $-0.5 \mathrm{~s}$ curve in the north, as well as in the south of $10^{\circ} \mathrm{S}$ where this zone bends southwestward in the same way as the zone of gravity low of Fig. 5 and 6. This observation shows close correlation between P-wave low-velocity and gravity low zones.

South of $10^{\circ} \mathrm{S}$ interpretation of long period record of surface waves without any a priori geological constraints revealed a decrease of SV velocity at $165 \mathrm{~km}$ under the Proterozoic belts of the southeast of D.R. Congo and Zambia (Hadiouche and Jobert, 1988). Correlation between this observation and the predicted gravity low trending NE-SW (Slettene et al., 1973) led to conclude that this zone which is also of plateau uplift along the NE-SW axis is of thinned lithosphere (Brown and Girdler, 1980; Hadiouche and Jobert, 1988). A similar result has been obtained in southern Africa from the previous study of Bloch et al. (1969).

In addition, the southeast of D.R. Congo and Zambia have been recognized by seeveral researchers to be of seismically most active regions in Africa (e.g. Dorbath, oral communication, 1992; Fairhead and Henderson, 1977; Grimison and Chen, 1988; Scholz et al., 1976; Sebagenzi et al., 1993; Shudofsky, 1985). Most of data used here are old because we have difficulties to access to the recent publications. However seismic events with $\mathrm{Mb} \geq 5.0$ occur almost every two years showing the seismicity axis parallel to NE-SW trending of the gravity low and plateau uplift zone (see unpublished bulletin of seismological stations around the world). The earthquake of september 1992 (see Fig. 13) which may be considered to be representative, fall into those with focal depth around $20 \mathrm{~km}$ in the lower crust (Dorbath, personal communication). So, it belongs to the group of deep seismic events of the EARS which indicate that brittle deformation occurs in the lower crust and that the lithosphere is old and unusually strong (e.g. Camelbeeck and Iranga, 1996; Jackson and Blenkinsop, 1993; Seno and Saito, 1994).

Two zones of strain concentration are identified from recent seismicity observed within Africa continent between $10^{\circ} \mathrm{S}$ and $20^{\circ} \mathrm{S}$; one from Tanzania accross the Mozambique Channel to the Davie Ridge-Madagascar and the other from Lake Tanganyika to the southeast of D.R. Congo and Zambia suggesting extensional stress field along the EARS. From analysis of the focal mechanism solutions which are all of normal faulting, several authors proposed to consider the for- 


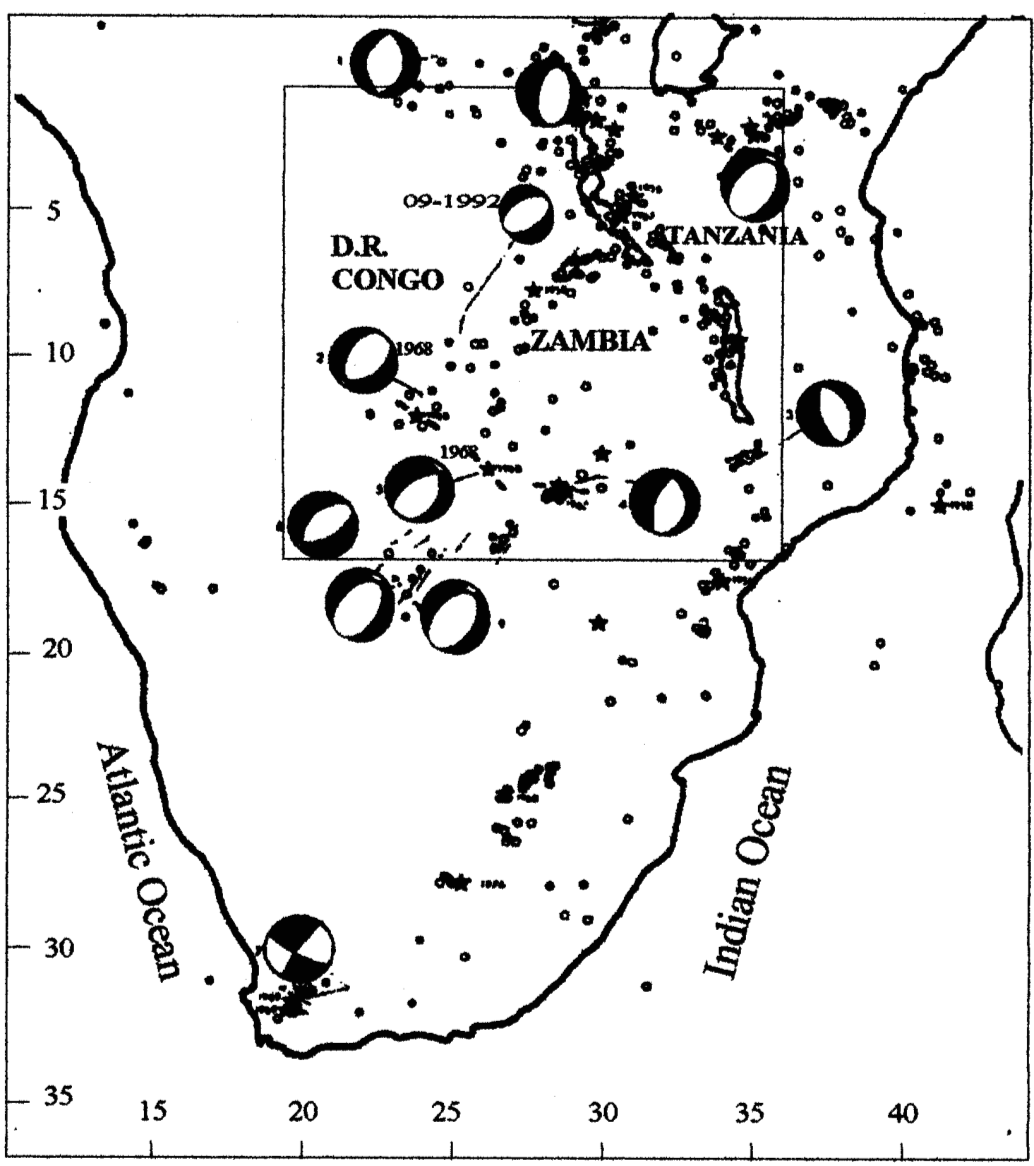

Fig. 13. Seismicity map of southern Africa for earthquakes with magnitude $\mathrm{Mb} \geq 5.0$ with available focal mechanism studies (redrawn from Sebagenzi et al., 1993). mer as the southeastward continuation of Eastern Branch, while the latter may constitute the southwestward extension of Western Branch of the EARS, where crustal extension deduced from the focal mechanisms solutions has a tensional stress axis perpendicular to the axis of the lithosphere thinning (Fairhead and Henderson, 1977; Grimison and Chen, 1988; Sebagenzi, 1997).

\section{Discussion}

The geophysical results reviewed in this paper bring substantial support to better understand present rift processes in the studied region where rifting started early. During the Mesozoic, opening of the Atlantic was accompanied by deformations within the adjacent African and South American plates. These intra-plate deformations were concetrated on pre-existing zones of crustal weakness provided by the Meso- and Neoproterozoic fold belts (McConell, 1972). In the southeast of D.R. Congo and Zambia the Karoo age tectonics followed by Cenozoic to present events, have been a rejuvenation of pre-existing structures (e.g. Delvaux, 2001; Theunissen et al., 1996). Evidence for renewed tectonic activity are given by the presence of faults in the basement which are parallel to the faults cutting into the sedimentary formations (Mondeguer et al., 1989; Tshimanga et al., in preparation). The opening of the NE-SW trending Upemba and Luano-Luangwa-Lukusashi Karoo basins was related to crustal extension during the break up of the Gondwana (Daly et al., 1989), while the Mwero was opened during the Cenozoic rifting episode (Mondeguer et al., 1989). According to seismological data both Karoo and Cenozoic rifts which nowadays are still opening may correspond to incipient arms of the EARS (e.g. Camelbeeck and Iranga, 1996; Fairhead and Girdler, 1972; Fairhead and Henderson, 1977; Lombe and Mubu, 1992). This present crustal extension has a tensional stress axis perpendicular to the NE-SW trending axis of the regional gravity low parallel to the lithosphere thinning axis (e.g. Fairhead and Henderson, 1977; Sebagenzi, 1997; Sebagenzi et al., 1993).

Rifting basins which is developed following Proterozoic weak trends in the crust may provide an example of the early phase of the crustal weakness dominated break up which starts with surface faulting and half grabens formations. Following Dunbar and Sawyer (1989) volcanism occurs later, as the focused extension within the crust propagates downward into the mantle. In addition low rates of lithospheric thinning is noticeable. Such is the case for the studied region where most of basins represent half-grabens or pull-apart troughs resulting of extension and strike-slip motions, and the local directions of extension derived from the fault plane striations 
as well as from tensional joints is generally NW-SE (Mondeguer et al., 1989; Tshimanga et al., in preparation). In contrast, mantle weakness dominated break up begins with diffuse surface faulting followed closely by volcanism. Localized surface faulting and graben formation occurs later in the extension process, and high rates of lithospheric thinning occur.

It has been demonstrated that present rifting which occurs in an old and strong lithosphere according to seismological data, is a consequence of a replacement of the colder and denser low part of the lithosphere by hot asthenosphere that commenced during the Cenozoic rifting period. This replacement would raise the surface elevation $(1450 \mathrm{~m}$ altitude) of the Kundelungu plateau (Sebagenzi, 1997). Therefore, since that time active rifting succeeded to "passive" rifting related to the opening of the South Atlantic.

Complete analysis of the gravity low pattern from Kenya ( $-200 \mathrm{mgal}$ amplitude) where the EARS is well developed to the southeast of D.R. Congo and Zambia where the anomaly attains $-140 \mathrm{mgal}$ amplitude, has suggested that this gravity pattern may reflect the topography of the boundary depth between the lithosphere and low-density asthenosphere which deepens southward (Sebagenzi, 1997). Together with HFD which suggested occurrence of partial melting zones at shallow depth (Sebagenzi et al., 1993), these results support the model of the opening "en ciseaux" proposed in the Western Branch involving an extension rate higher in the north than in the south (e.g. Kampunzu et al., 1982, 1998). Since the Cenozoic time, the upward movement of the lithosphereasthenosphere boundary which is less in the south of $10^{\circ} \mathrm{S}$ would attain $42 \mathrm{~km}$ amplitude when the base level of the lithosphere is fixed to $165 \mathrm{~km}$ (Sebagenzi, 1997), implying an upward rate of about $0.2 \mathrm{~mm} / \mathrm{y}$. This depth which was adopted to be the base level coincides with a decrease of SV velocity under the Proterozoic belts of the southeast of D.R. Congo and Zambia (Hadiouche and Jobert, 1988).

The studied region which is an example of time and again reactivation of pre-existing crustal discontinuities presents similarities with most of the well documented cases of rift that tensionally reactivated after more than $100 \mathrm{Ma}$ of tectonic quiescence since the preceding rift stage (e.g. Delvaux, 2001). Some 200 Ma elapsed between the Karoo and the Cenozoic rifting period. The present cycle followed after a much longer period of tectonic quiescence. In order to explain the timing and nature of repeated reactivation of basin systems, the mechanical weakening process applied for the Ubende belt by Delvaux (2001) would be adopted here. Following this process, during the Karoo period the stretched lithosphere is re-equilibrated and becomes rheologically stronger than the adjacent unstretched lithosphere. This increase in strength tends to lock the system and impedes further deformation of the basin (Ziegler et al., 1995). Therefore, localised deformation are probably controlled by lithospheric strength reduction due to the presence of preexisting crustal, and possibly also mantle-lithosphere discontinuities (Delvaux, 2001; Ziegler, 1990). These discontinuities permanently weaken the lithosphere and provide weak- ness zones that can be reactivated during the next tectonic stage, as long as the new stress tensor is adequate and has the suitable orientation relatively to the the pre-existing discontinuities (Delvaux, 2001).

The new geophysical results suggest that the rifting occurs in unusually strong lithosphere, as a result of the action of far-field intraplate stress produced at the plate boundaries similar to that of modern opening of the Baikal rift (Delvaux, 1997). It is controlled by the presence of lithospheric discontinuities that can be tensionaly reactivated. The history of rifting commences in the Late Carboniferous-Triassic period as a manifestation of the early stages of Gondwana break up in East-Central Africa. This intraplate deformations have been induced by stress transmission through continental lithosphere over long distances from both the southern and the northern (Neo-Tethys) margins of the Gondwana continent (Delvaux, 2001). After a period of tectonic quiescence the Cenozoic to present extensional events followed in response to an upward of the lithosphere asthenosphere boundary. These periods correspond to the "active rift" stage that succeeded to a "passive rift" stage.

\section{Conclusions}

The southeast of D.R. Congo and Zambia lie in region of considerable tectonic interest because of the southwestward continuation of the EARS. According to the geophysical results reviewed in this paper the most important geotectonic feature is the break up of Africa south of $10^{\circ} \mathrm{S}$ through the region, rifting evolution dependent on the extent of the asthenosphere upwelling. Seismicity especially indicates that extensional deformations are now taking place and conductive heat flow together with the gravity low reflect the occurrence of a hot and low density body in the upper mantle rising more and more. As elsewhere in Africa, faulting mainly follows earlier lines of weakness in the Precambrian basement and tectonic reactivation occurs throughout the history of the rift. So, the Karoo age tectonics followed by Mesozoic and later by the Cenozoic to present events, have been a rejuvenation of pre-existing structures.

Analysis of regional Bouguer anomaly pattern is a prime result of the study. From Kenya ( -200 mgal amplitude) toward the southeast of D.R. Congo and Zambia $(-140 \mathrm{mgal}$ amplitude), the gravity low over this region of seismicity and plateau uplift along the NE-SW axis may be considered as the reflected picture of the lithosphere-low density asthenosphere boundary which deepens southward.

HFD measurements which were made in this region provide evidence for the existence of zones of partial melting at $85-110 \mathrm{~km}$ depth. Thus, correlation between heat flow and the gravity low implies that the upper mantle beneath Southeastern D.R. Congo and Zambia is an anomalously hot region containing low-density and obviously low-velocity material. Here seismic soundings and teleseismic P-wave propagation are needed. 
In spite of the lack of recent volcanism, seismicity is sufficient to delineate the zones of incipient rifting in the southeast of D.R. Congo and Zambia where seismic events with $\mathrm{Mb} \geq 5.0$ occur during these years showing the seismicity axis parallel to NE-SW trending of the gravity low and plateau uplift zone.

In conclusion, it seems now justifiable to speculate that the EARS may extend southweastward along the region forming the watershed between the Congo and Zambezi River basins and, further to the west crossing Botswana and Namibia where the negative regional Bouguer anomaly is almost in continuity with the Walvis Ridge which connects the west coast of Africa to the mid-Atlantic ridges. Although the surface structure is now documented, its relationship to deeper features is not yet known. As rifting is a key process in the evolution of the continents, further geophysical data are needed for determining the deep structure of the southeast of D.R. Congo and Zambia to better understand rifting processes.

Acknowledgements. We are grateful to the GECAMINES General Direction for the authorization to participate in the Dead Sea, Israel June 11-16, 2000 First Stephan Mueller Conference of the European Geophysical Society (EGS). This paper has benefited greatly from valuable reviews and comments of Damien Delvaux and an anonymous reviewer.

\section{References}

Achauer, U.: A study of the Kenya rift using delay-time tomography analysis and gravity modelling, Tectonophysics, 209, 197-207, 1992.

Brown, C. and Girdler, R. W.: Interpretation of African gravity and its implications for the break-up of the continents, Journal of Geophysical Research, 85, 6443-6455, 1980.

Bloch, S., Hales, A. L. and Landisman, M.: Velocities in the crust and upper mantle of southern Africa, Bull. seism. Soc. Am., 59, 1599-1629, 1969.

Camelbeeck, T. and Iranga, M. D.: Deep crustal earthquakes and active faults along the Rukwa trough, eastern Africa, Geophys. J. Int., 124, 612-630, 1996.

Chapman, D. S. and Pollack, H. N.: Heat Flow and Heat Production in Zambia: Evidence for lithospheric thinning in Central Africa, Tectonophysics, 41, 79-100, 1977.

Chorowicz, J.: Le Rift Est-African: début d'ouverture d'un océan?, Bull. Centres Rech. Explor.Prod. Elf Aquitaine, 7, 1, ISSN; 0396-2687. CODEN: BCREDP, 155-162, 1983.

Cowan, M. P. and Pollack, H. N.: Gravity in Zambia, Reprinted from Nature, 266, 5603, 615-617, 1977.

Daly, M. C. and Unrug, R.: The Muva Supergroup of northern Zambia: a craton to mobile belt sedimentary sequence, Trans. Geol. Soc. South Africa, 85, 155-165, 1983.

Daly, M. C., Chorowicz, J., and Fairhead, J. D.: Rift basin evolution in Africa: the influence of reactivated steep basement shear zones, in: Cooper, M. A. and Williams, G. D. (Eds.): Inversion tectonics, Geological Society, London, Special Publication, 44, 309-335, 1989.

Delvaux, D.: The Karoo to Recent rifting in the western branch of the East-African rift system: A bibliographical synthesis, Mus.
Roy. Afr. Centr., Tervuren (Belg.), Dépt. Géol. Min., Rapp. ann. 1989-1990, 63-83, 1991.

Delvaux, D.: Geodynamics of Baikal Rifting: new developments and perspectives, in: Brian, A. W., Delvaux, D., and Khan, M. A. (Eds.): Lithospheric Structure, Evolution and Sedimentation in Continental Rifts, Communications of the Dublin Institute for advanced studies, Series D, Geophysical Bulletin, 48, 1997.

Delvaux, D.: Karoo rifting in western Tanzania precursor of Gondwana break-up. Contributions to the Geology and Paleontology of Gondwana, in: Honour of Helmut Wopfner, Cologne, 111125, 2001.

Dunbar, J. A. and Sawyer, D. S.: How Preexisting Weaknesses Control the Style of Continental Breakup, Journal of Geophysical Research, 94, B6, 7278-7292, 1989.

Fairhead, J. D.: The structure of the lithosphere beneath the eastern rift, East Africa, deduced from gravity studies, Tectonophysics, 30, 269-298, 1976.

Fairhead, J. D.: Mesozoic plate tectonic reconstructions of the Central South Atlantic Ocean: The role of the West and Central African rift system, Tectonophysics, 155, 181-194, 1988.

Fairhead, J. D. and Binks, R. M.: Differential opening of the Central and South Atlantic Oceans and the opening of the West African rift system, Tectonophysics, 187, 191-203, 1991.

Fairhead, J. D. and Girdler, R. W.: The seismicity of the East African rift system, Tectonophysics, 41, 19-26, 1972.

Fairhead, J. D. and Henderson, N. B.: The seismicity of southern Africa and incipient rifting, Tectonophysics, 41, 19-26, 1977.

Fairhead, J. D. and Reeves, C. V.: Teleseismic delay times, Bouguer anomalies and inferred thickness of the African lithosphere, Earth and Planetary Sciences Letters, 36, 63-76, 1977.

Grimison, N. L. and Chen, W. P.: Earthquakes in Davie RidgeMadagascar Region and the Southern Nubian-Somalian Plate Boundary. Journal of Geophysical Research, 93, B9, 10439 $10450,1988$.

Guiraud, R. and Maurin, J. C.: Early Cretaceous rifts of Western and Central Africa: an overview, Tectonophysics, 213, 153-168, 1992.

Hadiouche, O. and Jobert, N.: Geographical distribution of surfacewave velocities and 3-D upper mantle structure in Africa, Geophysical Journal, 95, 97-109, 1988.

Jackson, J. and Blenkinsop, T.: The Malawi Earthquake of march 10, 1989: deep faulting within the East African Rift System, Tectonics, 12, 5, 1131-1139, 1993.

Jones, L., Mathieu, P. L., and Strenger, H.: Résultats scientifiques des missions du Syndicat pour l'étude géologique et minière de la cuvette congolaise et travaux connexes. Géodesie et Géophysique, Ann. Mus. Roy. Congo Belge, Tervuren, Belgique, Sér. in-8 ${ }^{\circ}$ Sc. Géol., 36, 1960.

Kampunzu, A. B., Sebagenzi, M. N., Caron, J. P. H., and Vellutini, P. J.: Comparaison pétrochimique entre les laves du champ du Sud-Kivu (Bukavu) et du Nord-Kivu (Virunga), Zaïre, Annales Société Géologique Belgique 105, 25-29, 1982.

Kampunzu, A. B., Bonhomme, M. G., and Kanika, M.: Geochronology of volcanic rocks and evolution of the Cenozoic Western Branch of the East African Rift System, Journal of African Earth Sciences, 26, 3, 441-461, 1998.

Klerkx, J., Theunissen, K., and Delvaux, D.: Persistent fault controlled basin formation since the Proterozoic along the Western Branch of the East African Rift, Journal of African Earth Sciences, 26, 3, 347-361, 1998.

Lombe, K. D. and Mubu, M. S.: Instrumentation and seismicity in Zambia, Tectonophysics, 209, 31-33, 1992. 
Maasha, N. and Molnar, P.: Earthquake fault parameters and tectonics in Africa. Journal Geophys. Res., 77, 5731-5743, 1972.

Mazac, O.: Reconnaissance gravity survey of Zambia, Zambia Geol. Survey Tech. Report, 76, 40p, 1974.

McConnell, R. B.: Geological development of the rift system of eastern Africa, Bull. Geol. Soc. Am., 83, 2549-2572, 1972.

Mondeguer, A., Ravenne, C., Masse, P., and Tiercelin, J.-J.: Sedimentary basins in an extension and strike-slip background. The "South Tanganyika troughs complex", East African Rift, Bull. Soc. Geol. France, 8, V, 501-522, 1989.

Mortelmans, G.: Les antécédents tectoniques du graben de l'Upemba. Bulletin volcanologique, 13, 93-98, 1953.

Nyblade, A. A. and Pollack, H. N.: A gravity model for the lithosphere in Western Kenya and Northern Tanzania, Tectonophysics 212, 257-267, 1992.

Nyblade, A. A., Pollack, H. N., Jones, D. L., Podmore, F., and Mushayandebvu, M.: Terrestrial Heat Flow in East and Southern Africa. Journal of Geophysical Research, 95, B11, 17, 371-384, 1990.

Rapp, R. H., Wang, Y. M., and Pavlis, N. K.: The Ohio State 1991 Geopotential and Sea Surface Topographic Harmonic Coefficient Models. Report No 410, 1991, Department of Geodetic Science and Surveying, The Ohio State University, 1991.

Scholz, C. H., Koczynski, T. A., and Hutchins, D. G.: Evidence for incipient rifting in southern Africa, Geophysical Journal of Royal Astronomic Society, 44, 135-144, 1976.

Sebagenzi, M. N.: Etude gravimétrique et géothermique du SudEst du Zaïre et du Nord de la Zambie (Afrique centrale), PHD Thesis, University Paris 7, 272pp (unpublished), 1993.

Sebagenzi, M. N.: Gravity modelling of the lithosphere in Southeastern Zaïre and Zambia (Central Africa), Africa Geoscience Review, 4, 2, 153-175, 1997.

Sebagenzi, M. N., Vasseur, G., and Louis, P.: Recent warming in Southeastern Zaïre (Central Africa) inferred from disturbed geothermal gradients, Palaeoclimatology, Palaeoecology, Palaeogeography (Global Planetary Section), 98, 209-217, 1992.
Sebagenzi, M. N., Vasseur, G., and Louis, P.: First heat flow density determination from Southeastern Zaïre (Central Africa), Journal of African Earth Sciences, 16, 4, 413-423, 1993.

Seno, T. and Saito, A.: Recent East African earthquakes in the lower crust, Earth and Planetary Science Letters, 121, 125-136, 1994.

Shudofsky, G. N.: Source mechanisms and focal depths of EastAfrican earthquakes using Raleigh-waves inversion and bodywave modelling, Geophysical Journal of Royal Astronomic Society, 44, 135-144, 1985.

Slettene, R. L., Wilcox, R. S., Bouse, R. S., and Sanders, J. R.: Bouguer gravity anomaly map of Africa, U.S. Defence Mapping Aerospace Center, 2nd ed., 1973.

Talwani, M., Worzel, J. L., and Landisman, M.: Rapid gravity computating from two dimensional bodies with application to the Mendocino submarine fracture, Journal of Geophysical Research, 64, 49-59, 1959.

Theunissen, K., Klerkx, J., Melnikov, A., and Mruma, A.:Mechanism of inheritance of rift faulting in the western branch of the East Africa Rift, Tanzania, Tectonics 15(4), 776790, 1996.

Unrug, R.: The mid-Proterozoic Mporokoso Group of northern Zambia: startigraphy, sedimentation and regional position, Precambr. Res. Amsterdam, 24, 99-121, 1984.

Vauchez, A., Barruol, G., and Tommasi, A.: Why do continents break-up parallel to ancient orogenic belts? Terra Nova, 9(2), Oxford, 62-66, 1997.

Villeneuve, M.: Les sillons tectoniques du Précambrien supérieur dans l'Est du Zaïre, comparaison avec les directions du Rift EstAfricain, Bull. Centre Rech. Expl. Prod. Elf-Aquitaine, 7, 163174, 1983.

Ziegler, P. A.: Geological Atlas of Western and Central Europe, 2nd ed., Shell International Petroleum Mij. B. V., The Hague, 1-232, 1990.

Ziegler, P. A., Cloethingh, S., and Van Wees, J.-D.: Dynamics of intra-plate compressional deformation: the Alpine foreland and other examples, Tectonophysics, 252, 7-59, 1995. 